\title{
A NEW INVESTIGATION OF VIETNAM'S BERYL
}

\author{
Nguyen Van Binh and Nguyen Thi Hong \\ Institute of Materials Science \\ Vietnamese Academy of Science and Technology \\ 18 Hoang Quoc Viet, Cau Giay, Ha Noi, Vietnam
}

Received 06 January 2006

\begin{abstract}
The paper presents briefly new investigation of Vietnam beryl group, especially some characteristics of regional geology of Song Chay granite massif and new find of big crystals of beryl in them. The green beryl is found in quartz - mica - tourmaline, mica - feldspar - quartz pegmatite bodies in the south part of Song Chay granite - gneiss massif near Na Chi and Tan Nam villages, Quang Binh district, Ha Giang province.
\end{abstract}

Keywords: beryl, gemstones, mineralogical properties

\section{INTRODUCTION}

The beryl group consists of some members: beryl Be3Al2[Si6O18] (Emerald, Aquamarine, Morganite, Heliodor, Goshenite, Rosterite etc.), Vorobievite CsBe3A12[Si6O18], Stoppaniite: $\mathrm{Be3}(\mathrm{Fe}, \mathrm{Al}$ )2[Si6O18], Pezzottaite: CsBe2LiAl2[Si6O18], Bazzite: Be3(Sc,Al)2[Si6O18] etc. of these, only beryl (emerald, aquamarine) and pezzotaite have been found in gem quality.

In recent years, many kinds of gemstones have found in Viet Nam, such as: ruby, sapphir, spinel, tourmaline, garnet, margarite, pargasite, zircon etc. Many of them have been exploited. Mineral beryl is found in many places of Viet Nam: Thach Khoan (Phu Tho province in North Viet Nam), Thuong Xuan (Thanh Hoa province in Central Viet Nam) and Bu Khang (Nghe An province in Central Viet Nam). In this paper, the authors present new investigation of Vietnam beryl group, especially some new information on beryl found in Song Chay massif (Ha Giang province, Viet Nam).

\section{THE OCCURRENCES OF BERYL IN NORTH VIET NAM}

\subsection{The Xuan Le deposit (Thuong Xuan district, Thanh Hoa province)}

In Xuan Le deposit had found aquamarine in pegmatite vein related with biotite granite and grano - syenite, granophyric granite, quartz syenite. Beryl is formed in pegmatite bodies and distributed inside or at the margin of the intrusive massif. The pegmatite bodies are usually in the form of pocket, lenses, some in the form of veins with varied size. The big bodies are tens meters long and small ones are $10-30 \mathrm{~cm}$ thick and extend a few meters in length. Beryl crystals are disseminated in the pegmatite. Together with beryl there are topazes, quartz, and opal. The beryl crystals are small in size (1 - $5 \mathrm{~mm}$ long) account for $1-5 \%$ of total minerals, in individual cases up to $30-40 \%$. In the primary ore no beryl crystals with jewelry standard have been found. But in the placer have found beryl meeting in the commercial requirement (aquamarine). 


\subsection{The Deo Sen beryl occurrence (Quy Chau district, Nghe An province)}

The Deo Sen beryl occurrence is located in the north of $\mathrm{Bu}$ Khang dome. Hiere, beryl is distributed in the pegmatite bodies 2 - $3 \mathrm{~m}$ thick, extending 40 - $50 \mathrm{~m}$ long. The grade of beryl in pegmatite bodies has not been evaluated. The prospect of the ore occurrence is not clear yet.

\subsection{Thach Khoan deposit (Thanh Son district, Phu Tho province)}

The Thach Khoan deposit composed of many occurrences: Di Nau, Doi Dao, Mo Ngot etc.. In Thach Khoan deposit beryl (aquamarine etc.) are found with white mica, tourmaline, feldspar and crystal quartz.

\subsection{The Song Chay occurrence (Quang Binh district, Ha Giang province)}

In 2004 year, we found big crystal of beryl in muscovite - feldspar - quartz pegmatite, tourmaline pegmatite bodies in Song Chay granite - gneiss massif. In the same Song Chay massif, the Chinese geologists have found crystal emerald in the Chinese part of Song Chay massif nearby to China - Vietnam boundary.

\subsubsection{Location}

The investigation area is located about $300 \mathrm{Km}$ north of Ha Noi capital in Quang Binh district, Ha Giang province. In Song Chay massif, big crystals of beryl are found $\mathrm{nm}$ in south-east of $\mathrm{Na}$ Chi and Tan Nam villages, Quang Binh District, Ha Giang Province (North Viet Nam).

\subsubsection{Regional geology}

The geological map of Song Chay granite - gneiss dome is showed in figure 1. The Song Chay massif is one of the biggest intrusive massifs in Vietnam $\left(2500 \mathrm{~km}^{2}\right)$. The Song Chay massif is located in the North East Vietnam Para - fold Region (Song Lo Zone) belongs to the Sino Vietnamese Fold system which was consolidated in Late Caledonian. The Song Lo Zone (including Song Chay massif) is bounded by the Ha Giang - Thanh Thuy fault in the northeast and Song Chay fault in the southwest. It is composed of largely distributed Neoproterozoic to Paleozoic sediments forming a large anticlinorium, where a large granite - gneiss batholiths penetrated in the core, forming the Song Chay dome.

In the investigation area, there exist following formations:

- Song Chay Group. The Song Chay Group is composed of terrigeno- carbonate sediments metamorphosed to the epidote - amphibolite and green schist facies, distributed in large bands in the east of the Song Chay massif. It has been subdivided into 2 Formations: An Phu and Thac $\mathrm{Ba}$ ones. The Thac Ba Formation $\left(\mathrm{PR}_{3}-\varepsilon_{1} t b\right)$ is composed of quartz - feldspar - mica schist bearing garnet with lenses of hornblende plagioclase - epidote schist, quartz - feldspar - two mica schist interbedded with quartzite and calcite - epidote - tremolite schist. The An Phu Formations $\left(\mathrm{PR}_{3}-\varepsilon_{1} a p\right)$ is composed of marble bearing graphite, dolomite marble interbedded with two mica schist, feldspar - calcite schist and distributed in some small areas in the forms of xenoliths within this massif.

- Ha Giang Formation $\left(\varepsilon_{2} \underline{h g}\right)$. The Ha Giang Formation is largely distributed around the Song Chay massif. The Ha Giang Formation is composed of quartz - biotite schist bearing garnet; sericite - chlorite schist, shungite with some lenses of marbleized limestone bearing oncolite; brecciated limestone phyllite, oolitic limestone marble, clayey limestone.

- Chang Pung Formation $\left(\varepsilon_{3} \underline{c p}\right)$. The Chang Pung Formation is distributed in the northeast and 
west of the Song Chay massif. This formation is composed of clay - sericite schist grading upward to limestone calcareous clay shale, some beds of oolitic limestone, marlaceous shale, clay shale, limestone, oolitic limestone, clayey limestone and claystone.

- Mia Le Formation $\left(\mathrm{D}_{1} \frac{m l)}{2}\right.$. The Mia Le (Ma le) Formation is composed of clay - sericite shale, quartzitic sandstone, tuffoceous sandstone interbedded with felsic - alkaline effusives. The Mia Le Formation is rather largely distributed in the east and southeast of the Song Chay massif.

- Khao Loc Formation $\left(\mathrm{D}_{1-2} \underline{\mathrm{kl}}\right)$. In the investigated area, this Formation is distributed concentratedly in the southeast and east of the Song Chay massif. The Khao Loc Formation is composed of quartzite sandstone, limestone, calcitized limestone, quartz - sericite - chlorite schist, bituminous limestone, marlaceous shale, cherty limestone and calcareous shale.

- Yen Binh Formation $\left(\mathrm{T}_{2} y b\right)$. The Yen Binh Formation is exposed in some small areas in the north of the Luc Yen district, near the south margin of Song Chay massif. This formation is composed of conglomerate, grey polymictic sandstone, dirty - grey limestone, clay shale, motley colored clayey limestone, sandstone, siltstone.

- Ban Hang Formation (K? bh). The Ban Hang Formation is distributed in Yen Binh area, it is composed of polymictic conglomerate, gritstone, siltstone, calcareous sandstone, sandstone.

\section{Magmatic intrusions}

- Song Chay complex ( $\left.\rho \gamma a \mathrm{D}_{1} s c\right)$.

According to geology and mineral resource of Ma Quan and Bac Quan sheets (F - 48 - IX, F 48 - XV) the Song Chay complex comprises 3 phases: Phase 1: small to medium grained, porphyritic biotite granite. Mineral composition (\%): quartz 20 - 40, microcline 18 - 42, plagioclase 17 - 38, biotite 5 - 18. Accessory minerals: apatite, zircon, tourmaline, garnet, monazite and ilmenite. Phase 2: leucocratic, gneissoid coarse - grained biotite granite. Mineral composition (\%): quartz 20 - 38, microcline 30 - 50, plagioclase 10 - 28, biotite 6 - 10 , muscovite 1 - 4. Accessory minerals: apatite, zircon, monazite and garnet. Phase 3: vein rocks with aplite, garnet- bearing pegmatite. Petrochemical characteristics: rocks of the complex has the following content (\%): $\mathrm{SiO}_{2} 63-75, \mathrm{CaO} 0.1-2.4$, total alkali 4 - 9; they belong to the potassic or sodic - potassic alkaline type with $\mathrm{Na}_{2} \mathrm{O} / \mathrm{K}_{2} \mathrm{O} 0.4-0.8$. Geochemical characteristics: the content of $\mathrm{Sn}, \mathrm{Pb}$ and $\mathrm{Zn}$ elements is 2-3 times higher than Clarke value. The studied rocks belong to the $\mathrm{S}$ - granite type. A.P. Ponomeva [7] on the basis of geological and mineralogy geochemical studies divided four series of Song Chay massif granite. These are: sodium, K sodium, potassium and high potassium series varying from granitoites to leucocratic granites.

Rocks of the Song Chay complex penetrate metamorphic rocks of the Song Chay group, the Ha Giang $\left(\varepsilon_{2} h g\right)$ Formation and Chang Pung Formation $\left(\varepsilon_{3} c p\right)$. These have been existed various opinions on the datation of the Song Chay massif.

The isotope ages of the Song Chay granitoids by various methods [1, 5, 6 - 9]:

- 2652, 2452, 2050 (zircon; U - Th - Pb; migmatite, crystalline shale)

- 1007, 1000; 650, 625, 620 (zircon, apatite; $\mathrm{U}$ - Pb; gneissoid two mica granite);

- 465, 464, 452, 450, 428 (zircon, biotite; $\mathrm{U}$ - Pb, Rb - Sr; gneissoid two mica granite)

- 305, 300, 299, 295 245, 240, 236, 234, 230, 228, 222, 215, 212, 210, 201, 200, 198, 195, 194 , 192 (mica, feldspar; Ar - Ar; granitoids);

- 176, 175, 174, 166, 165, 164, 163, 160, 144, 101;

- 40, 28, 24, 23, 20, 19, 16 M.A. 
This data shows that granite of Song Chay massif has multistage generation.

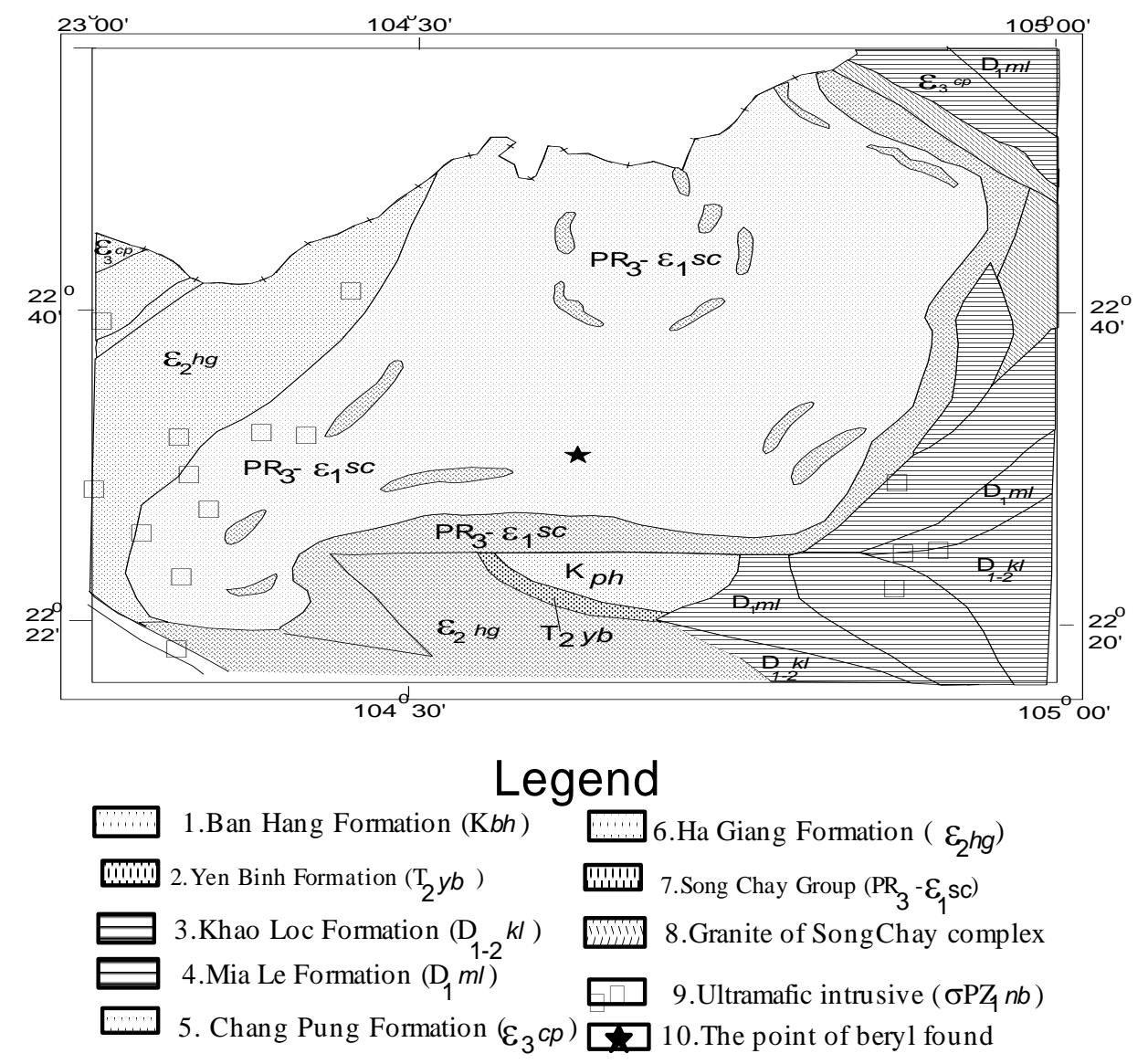

Fig 1: The geological map of investigation area.

\section{SOME RESULTS OF STUDY OF VIETNAM BERYL}

\subsection{Methods of the analyzes}

The above sample groups were firstly described visually in detail on their crystalline features, sizes, and angles between the sides... especially, the modern analyzing methods are also applied in studying their mineralogical nature such as: X-Ray diffraction method (New Material Center, Faculty of Physics, HUS and Institute of Materials Science); Microzond (Research Institute of Geology \& Mineral Resources (RIGMR)); Raman Spectroscopy (Spectra - gemological Laboratory, Institute of Materials Science); crystallographic optics and gemological method (VIGEMLAB - Institute of Gemology and Jewelry).

\subsection{Color characteristics}

The mineral color of the beryl group observed under the sun light by naked eyes is different according their origins (Table 1). 
Table 1: Typical mineral color of the beryl group.

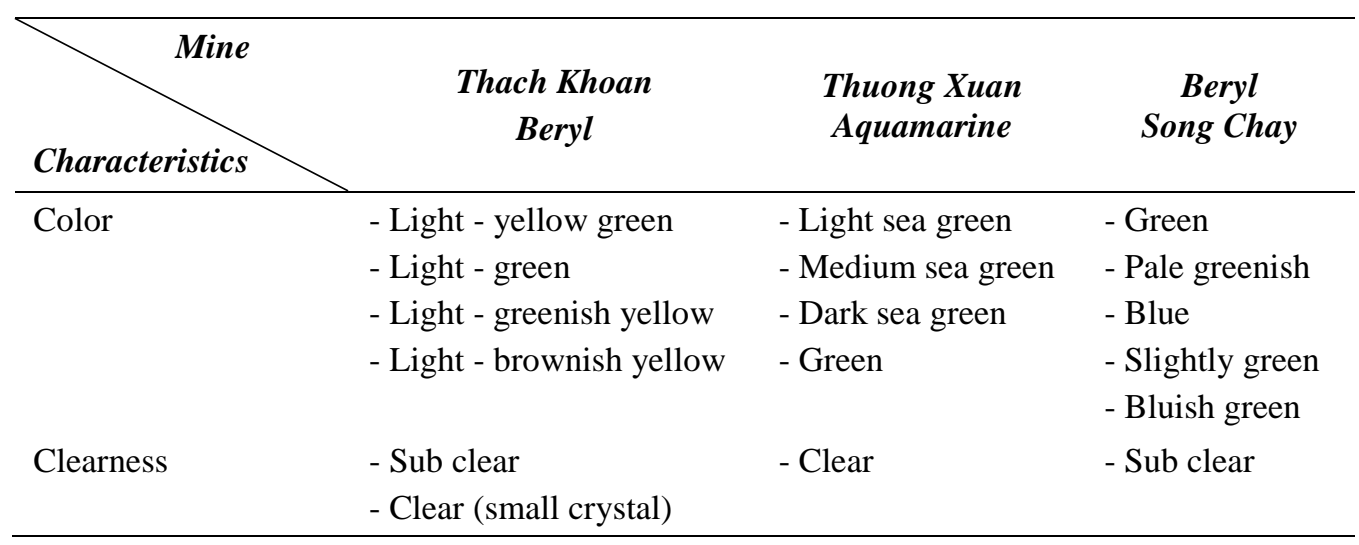

\subsection{Morphology}

The beryl group have typical prism form and usually found in single crystals, sometimes in crystal mass. Prism face $\{10 \overline{1} 0\}$ and double face $\{0001\}$ are widely developed. The pyramid face $\{11 \overline{2} 1\},\{10 \overline{1} 1\}$ and pyramid double face $\{11 \overline{2} 0\}$ are rarely found or poorly developed.

The measured angles between faces are as below:

$$
\begin{aligned}
& \{0001\} \wedge\{10 \overline{1} 1\}=29^{\circ} 50^{\prime}-29^{\circ} 56^{\prime} \\
& \{10 \overline{1} 1\} \wedge\{11 \overline{2} 0\}=64^{\circ} 15^{\prime}-64^{\mathrm{O}} 23^{\prime} \\
& \{0001\} \wedge\{11 \overline{2} 1\}=44^{\circ} 51^{\prime}-44^{\circ} 56^{\prime} .
\end{aligned}
$$

The sizes of mono crystal are various. The Thach Khoan beryl usually has an impressive size with height from several $\mathrm{cm}$ to $60-70 \mathrm{~cm}$ and weight of the crystal may reach nearly $100 \mathrm{~kg}$. The aquamarine crystals of Thuong Xuan Pegmatite deposit often have size of 0.1 to $15 \mathrm{~cm}$ with the weight reaches $700-800 \mathrm{~g}$. The Song Chay massif beryl forms hexagonal crystals (short prisms) hosted by feldspar, quartz, mica and black tourmaline. Individual crystal range to more $2-22 \mathrm{~cm}$ in diameter and $35 \mathrm{~cm}$ long.

\subsection{Chemical composition}

The results of chemical analysis are shown in table 2. It is clearly seen that main oxide compositions as $\mathrm{SiO}_{2}, \mathrm{Al}_{2} \mathrm{O}_{3}, \mathrm{BeO}$ are almost similar in all types of beryl. The differences in weight are in the range of analyzing method.

However, it is noted that there is some difference in the content of the color-bearing elements $\left(\mathrm{FeO}, \mathrm{MnO}\right.$, $\mathrm{NiO}$, and $\left.\mathrm{V}_{2} \mathrm{O}_{5}\right)$ and alkaline, earth alkaline elements $\left(\mathrm{CaO}, \mathrm{MgO}, \mathrm{Na}_{2} \mathrm{O}\right.$ and $\left.\mathrm{K}_{2} \mathrm{O}\right)$ between the beryl group.

The empirical mineralogical formulas of two types of beryl modifications have been calculated as follows:

+ Thach Khoan Beryl (TK-1):

$$
\left(\mathrm{Be}_{2,88} \mathrm{Fe}_{0,05} \mathrm{Mg}_{0,0024} \mathrm{Mn}_{0,004} \mathrm{Ca}_{0,002} \mathrm{Na}_{0,0034} \mathrm{~K}_{0,0036}\right)_{3} \mathrm{Al}_{2,00}\left[\mathrm{Si}_{6,02} \mathrm{O}_{18}\right] .
$$

+ Thuong Xuan Aquamarine (TX-1):

$$
\left(\mathrm{Be}_{2,97} \mathrm{Fe}_{0,06} \mathrm{Mg}_{0,0024} \mathrm{Na}_{0,004} \mathrm{~K}_{0,0031}\right)_{3} \mathrm{Al}_{2,00}\left[\mathrm{Si}_{6} \mathrm{O}_{18}\right] .
$$


Table 2: Results of chemical analysis.

\begin{tabular}{lllll}
\hline \multirow{2}{*}{ No. } & Oxide & \multicolumn{3}{c}{ Composition (\%) in monocrystals } \\
\cline { 3 - 5 } & & Thach Khoan beryl & $\begin{array}{l}\text { Thuong Xuan } \\
\text { aquamarine }\end{array}$ & Beryl Song Chay \\
\hline 1 & $\mathrm{SiO}_{2}$ & 63.97 & 66.25 & 65,02 \\
2 & $\mathrm{TiO}_{2}$ & 0.013 & 0.002 & 17,99 \\
3 & $\mathrm{Al}_{2} \mathrm{O}_{3}$ & 17.62 & 18.52 & \\
4 & $\mathrm{Cr}_{2} \mathrm{O}_{3}$ & 0.005 & 0.004 & \\
5 & $\mathrm{~V}_{2} \mathrm{O}_{5}$ & - & - & 0,33 \\
6 & $\mathrm{FeO}$ & 0.58 & 0.65 & \\
7 & $\mathrm{NiO}$ & 0.007 & 0.011 & 0,58 \\
8 & $\mathrm{BeO}$ & 13.32 & 13.21 & 0,57 \\
9 & $\mathrm{MgO}$ & 0.019 & 0.006 & 1,18 \\
10 & $\mathrm{CaO}$ & 0.015 & 0.002 & 0,55 \\
11 & $\mathrm{MnO}$ & 0.039 & 0.020 & \\
12 & $\mathrm{Na} 2$ & 0.032 & 0.023 & 0,99 \\
13 & $\mathrm{~K}_{2} \mathrm{O}$ & 0.021 & 0.012 & \\
14 & $\mathrm{P}_{2} \mathrm{O}_{5}$ & 0.016 & - & \\
15 & $\mathrm{H}_{2} \mathrm{O}$ & & & \\
\hline
\end{tabular}

\subsection{Characteristics of absorption and raman spectra}

These properties were studied in the Laboratory of Spectroscopy and Gemology, Institute of Materials Science, Academy of Science \& Technology. Due to the shortage of the emerald samples, this type of test was only conducted for the Thach Khoan beryl and Thuong Xuan aquamarine. The results of the Raman \& absorption spectra analyses are shown in the table 3.

Table 3: Summary of analyzed values of Raman and absorption spectra.

\begin{tabular}{|c|c|c|}
\hline Spectra Types & Thach Khoan Beryl & Thuong Xuan Aquamarine \\
\hline Absorption & $\begin{array}{l}\text { - Wave length } 400 \text { - } 600 \mathrm{~nm} \\
\text { - Weak \& not clear spectra was } \\
\text { presented }\end{array}$ & $\begin{array}{l}\text { - Wave length } 410 \text { - } 600 \mathrm{~nm} \\
\text { - Clear spectra was clearly } \\
\text { presented at } 427 \& 456 \mathrm{~nm}\end{array}$ \\
\hline \multirow[t]{4}{*}{ Raman } & - Li-yellow green beryl (milky) & \multirow{4}{*}{$\begin{array}{l}\text { - Sea green aquamarine (clear) } \\
290.0 ; 325.0 ; 398.0 ; 424.0 ; 443.9 \\
528.7 ; 581.3 ; \text { } 681.1 ; 771.5 ; 1015.4 \\
1070.6 ; 1241.2\end{array}$} \\
\hline & $\begin{array}{l}323.9 ; 397.0 ; 422.2 ; 443.2 ; 530.4 \\
583.4 ; \underline{685.0} ; 771.5 ; 914.4 ; 1014.5 \\
1070.6 ; 1240.3\end{array}$ & \\
\hline & - Green beryl (milky) & \\
\hline & $\begin{array}{l}328.9 ; 397.0 ; 421.8 ; 447.4 ; 526.5 ; \\
623.8 ; \underline{685.0} ; 772.5 ; 915.3 ; 1010.5 \\
1067.7 ; 1240.5\end{array}$ & \\
\hline
\end{tabular}


As it is clearly seen from table 2, by comparing the determined spectra with the standard spectra, beryl and aquamarine could be easily distinguished. It shows that the absorption and Raman spectra are greatly depended on the content of the isomorphic elements in beryl crystalline structure.

\subsection{Crystalline structural characteristics}

Beryl of Song Chay massif was measured by $\mathrm{X}$ - ray diffractrometers (type Siements D500 by using $\mathrm{Cu}$-K $\alpha, \mathrm{X}$-ray tube, $\lambda=1.5406)$. X-ray metric: $\mathrm{a}=9.2121, \mathrm{~b}=9.2121, \mathrm{c}=9.1954, \mathrm{~V}=$ 675.794. The results are showed in table 5. and Fig. 2. : 3,238 (10) - 2,874 (10) - 2,146 (8) 1,989 (8) - 1,737 (8) - 1,515 (8) - 1,430 (8) - 1,276 (80 - 0,8066 [d(Cps)] (Fig. 2).

Table 4: Summary of calculated values of crystal lattice parameters of beryl group in Vietnam.

\begin{tabular}{|c|c|c|c|c|}
\hline $\begin{array}{l}\text { Parameters } \\
\text { of crystal } \\
\text { lattice }\end{array}$ & $\begin{array}{l}\text { Thach Khoan } \\
\text { Beryl }\end{array}$ & $\begin{array}{l}\text { Thuong Xuan } \\
\text { Aquamarine }\end{array}$ & $\begin{array}{l}\text { Beryl Song } \\
\text { Chay }\end{array}$ & Remark \\
\hline$a_{O}$ & $\begin{array}{l}9.2130 \pm 0.002 \\
9.2091 \pm 0.003\end{array}$ & $9.2073 \pm 0.007$ & $\begin{array}{c}\mathrm{a}_{0}=9.2121 \\
\mathrm{~b}_{0}=9.2121\end{array}$ & $\begin{array}{l}\text { Value } \mathrm{a}_{\mathrm{O}} \text { of beryl } \\
\text { aquamarine } \& \\
\text { emerald is stable }\end{array}$ \\
\hline $\mathrm{c}_{\mathrm{O}}$ & $\begin{array}{l}9.2126 \pm 0.008 \\
9.1934 \pm 0.001\end{array}$ & $9.1973 \pm 0.003$ & 9.1954 & $\begin{array}{l}\text { Value } c_{O} \text { change a } \\
\text { little }\end{array}$ \\
\hline $\mathrm{a}_{\mathrm{O}}: \mathrm{c}_{\mathrm{O}}$ & $\begin{array}{l}1: 0.9999 \\
1: 0.9982\end{array}$ & 1: 0.9989 & 1,0018 & $\begin{array}{l}\text { Value } a_{O}: c_{O} \text { of is } \\
\text { stable }\end{array}$ \\
\hline
\end{tabular}

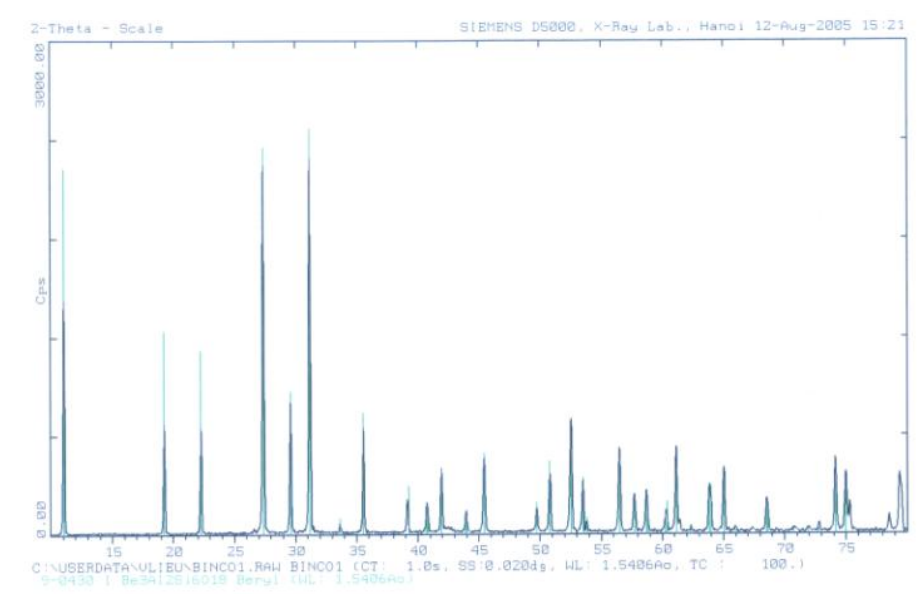

Fig. 2: Typical XRD pattern of the Song Chay green beryl. 
Table 5: Result of X-ray diagram calculation of Song Chay massif.

\begin{tabular}{|c|c|c|c|c|c|}
\hline dA & Int & H k l & dA & Int & H k l \\
\hline 7.98 & 90 & 100 & & & \\
\hline 4.60 & 50 & 002 & 1.7110 & 14 & 411 \\
\hline 3.99 & 45 & 200 & 1.7007 & 4 & 322 \\
\hline 3.254 & 95 & 112 & & & \\
\hline \multirow[t]{2}{*}{3.015} & 35 & 210 & 1.6265 & 18 & 224 \\
\hline & & & 1.5953 & 8 & 500 \\
\hline 2.867 & 100 & 211 & 1.5710 & 10 & 323 \\
\hline 2.660 & 4 & 300 & 1.5690 & 8 & 215 \\
\hline 2.523 & 30 & 212 & 1.5349 & 6 & 330 \\
\hline 2.293 & 12 & 004 & & & \\
\hline \multirow[t]{2}{*}{2.213} & 8 & 310 & 1.5320 & 8 & 006 \\
\hline & & & 1.5138 & 16 & 413 \\
\hline 2.208 & 4 & 104 & 1.4882 & 2 & 421 \\
\hline 2.152 & 16 & 311 & 1.4566 & 10 & 332 \\
\hline 2.060 & 4 & 222 & 1.4535 & 12 & 116 \\
\hline 2.056 & 6 & 114 & & & \\
\hline \multirow[t]{2}{*}{1.9926} & 20 & 204 & 1.4324 & 14 & 324 \\
\hline & & & 1.4148 & 2 & 315 \\
\hline 1.8308 & 8 & 320 & 1.3682 & 8 & 512 \\
\hline 1.7954 & 18 & 321 & 1.3556 & 6 & 216 \\
\hline 1.7397 & 20 & 304 & 1.3306 & $<1$ & 600 \\
\hline
\end{tabular}

\section{THE POSSIBILITY TO FIND AQUAMARINE AND EMERALD IN SONG CHAY} MASSIF

In the Song Chay massif, the big green beryl is found in quartz - mica - tourmaline, mica feldspar - quartz pegmatite bodies. In the same Song Chay massif, the Chinese geologists have found crystal emerald in the Chinese part of Song Chay massif nearby to Chine - Viet Nam boundary. We thing that emerald and aquamarine are mostly found in Vietnamese part of Song Chay massif because in Song Chay massif there are many bodies of mafic and ultramafic rocks penetrate granitoide rocks (see Fig. 1).


Fig. 3a: Beryl in Song Chay massif and The point detect on Song Chay's beryl. 

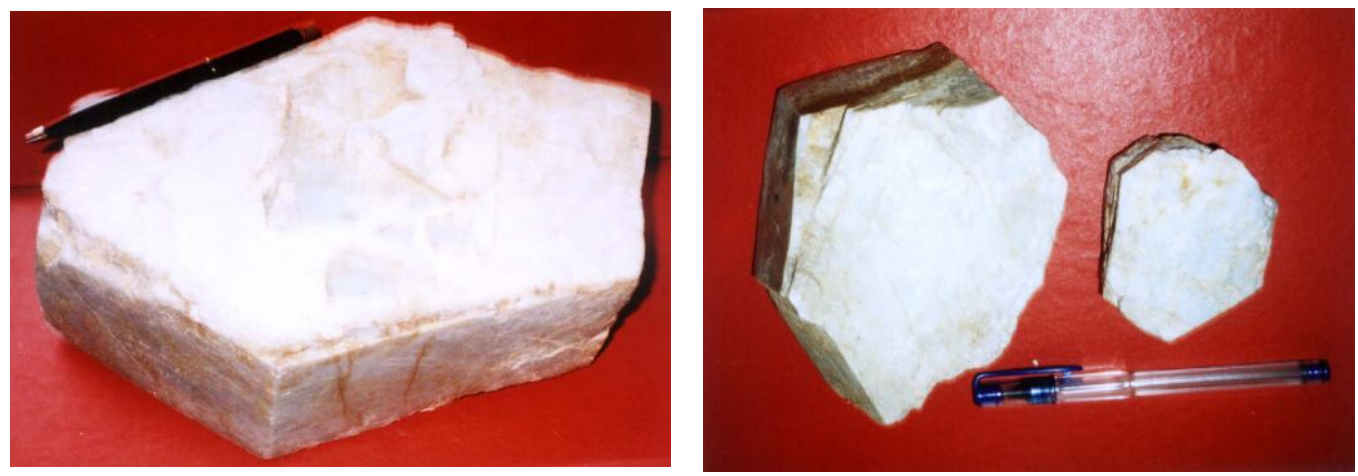

Fig. 3b: Beryl's crystal in Song Chay massif.

\section{CONCLUSION}

The Song Chay granite - gneiss massif is situated in Song Chay Precambrian folded zone which reformed in Paleozoic time and is belonging to the Precambrian oceanic types. The green beryl is found in quartz - mica - tourmaline, mica - feldspar - quartz pegmatite bodies in the south part of Song Chay granite - gneiss massif near Na Chi and Tan Nam villages, Quang Binh district, Ha Giang province.

The mineral beryl group of North Viet Nam is distributed mainly in the pegmatite related to acid magamtic. New discovries of gemstones occurrences allow us to suggest that in the future exploration will reveal additional deposist of economical significance

\section{REFERENCES}

1. Dovzhikov, A.E., et al. (1965), Geology of North Viet Nam, Ha Noi, p. 668 (in Russian).

2. Geology and mineral resources of Bac Quang sheet $(F-48-X V)$, scale 1: 200000 (Editor: Tran Xuyen), Ha Noi, 2001. (in Vietnamese).

3. Geology and mineral resources of Ma Quang sheet $(\mathrm{F}-48-\mathrm{XV})$, scale 1: 200000 (Editor: Tran Xuyen), Ha Noi, 2001. (in Vietnamese).

4. Geological map of Viet Nam scale 1: 500000 (Editor: Tran Duc Luong, Nguyen Xuan Bao), Ha Noi, 1981 - 1988. (in Vietnamese).

5. Geology of Viet Nam, Magmatic formations (Editor: Dao Dinh Thuc, Huynh Trung). Geol. Suvr. of Viet Nam. Vol. 2, p. 359 (in Vietnamese).

6. Izokh, E.P., Phan Viet Ky, Nguyen Van Quyen, Tran Quoc Hai, and Nguyen Thac Nhan (1981), Geological position and possible mechanism of Song Chay granite formation. “Geological Mapping”, No. 48, pp. 20 - 26. (in Vietnaese).

7. Ponmareva, A.P., Vladimirov, A.G., Phan Luu Anh, Krut, N.N., Rudnev, S.N., Ponomarchuk, V.A., Bibikova, E.V., and D.Z. Zhuravlov (1997), The Song Chay high alumina granite massif in Northern Viet Nam: substantiation of The Ordovician age, petrogenesis and tectonic position. J. "Russian Geology and Geophysics", pp. 1792 - 1806. (in Russian).

8. Ta Trong Thang, Vu Van Tich, and Le Thi Thu Huong (2002), Mesozoic - Cenozoic geodynamic evolution of the deformation area from Bu Khang to Song Chay dome. "J. of Sciences of the Earth. pp. 129 - 137. (in Vietnamese). 
9. Tugarinov, A.I., Nguyen Khac Vinh, Zykov, S.I., and Stubnikova, N.I. (1979), Pb - U geochronology of Song Chay granite Complex North Viet Nam). J. "Moscow University Geology Bulletin", pp. 94 - 97. (in Russian). 